\title{
GALDÓS AND GALDOSISTAS IN THE UNITED STATES: \\ ON THE FIFTIETH ANNIVERSARY OF THE AUTHOR'S DEATH
}

\author{
VERNON A. CHAMBERLIN \\ University of Kansas
}

\section{$\mathrm{T}$} HROUGHOUT 1970, the fiftieth anniversary of the death of Benito Pérez Galdós (1843-1920), the international world of literature is honoring the Spanish master's artistic achievement. ${ }^{1}$ Hispania is pleased to join such well-known journals as Symposium ${ }^{2}$ and Cuadernos hispanoamericanos $^{3}$ in dedicating an entire issue to Galdós' memory. ${ }^{*}$ The fact that this is the frst issue of Hispania ever dedicated completely to one author is indicative of the importance and high esteem which Galdós enjoys both in the field of Hispanic belleslettres and among the members of our own American Association of Teachers of Spanish and Portuguese.

Galdós, of course, would be the first to protest that he does not merit the honor we are paying him. Always a very shy and sincerely self-effacing individual, Galdós did, nevertheless, acquire national and international fame within his own lifetime; and now, fifty years after his death, he is generally considered the most important Spanish author of the nineteenth century and the greatest Spanish novelist since Cervantes. Creator of more than 8,000 fictional characters in seventy-seven novels, twenty-six plays, many short stories and several costumbrista sketches, Galdós achieved importance and esteem comparable to those of his nineteenth-century European con-

* The Editor wishes to express his gratitude and debt to the excellent galdosistas who here honor both Galdós and Hispania with their studies. He is most especially grateful to Prof. Vernon A. Chamberlin for his generous help in the preparation of the present number. Prof. Chamberlin's efforts on our behalf have, among other things, resulted in a particular coherence which such numbers as this do not always enjoy.-I. P. R. temporaries, Dickens, Balzac, Zola, Tolstoy, and Dostoievsky. At the time of his death in 1920, Galdós was so well-known and beloved by his fellow Spaniards that an estimated 30,000 people paid their respects as his body lay in state in the City Hall in Madrid and an even greater number honored him by marching in his funeral procession.

His novels were translated into many languages during his lifetime, and more translations are still being made. Several of Galdós' better-known works have also been adapted to the cinema (El abuelo, Doña Perfecta, Misericordia, and Nazarin among others), sometimes following faithfully the author's original intent, but often serving as an inspiration for an entirely new interpretation. 'Tristana and Fortunata y Jacinta $a^{4}$ have both appeared in film versions during 1970, the latter also having a successful run as a stage play in Spain this year. ${ }^{5}$ More doctoral dissertations have been written on Galdós than on any other Spanish author, including Cervantes. ${ }^{6}$ Thus Galdós' works manifest their universality; they transcend the time and place of their creation and continue to appeal to a wide audience today. Those of us who use Galdós' works for recreational reading, classroom teaching, and research are often grateful to Don Benito for many hours of pleasure and satisfaction.

Galdós was, in a sense, one of us, in that he strove untiringly throughout his long career to be an effective teacher, sincerely believing in both the novel and the theater as a means of education. Because he always retained the perspective and objectivity of an outsider (having been born and raised 
in the Canary Islands), Galdós was able to see with remarkable clarity the shortcomings of the Spanish nation and of its individual citizens as well. ${ }^{7}$ In his writing Galdós continually pointed out these basic weaknesses to his readers, sometimes with aggressive anger but more often with delightfully effective humor. History, politics, currents of social change, national traits, and individual foibles-all these and many more-received his careful attention, for he hoped that knowledge concerning them could eventually lead to change and an improvement in the Spanish condition, both for the nation and for the individual.

Never one to shirk his civic responsibilities, Galdós served during two different periods of his life as a deputy in the Spanish Cortes. At the time of his first period of service as a member of Sagasta's Liberal Party, Galdós defended the principle of an enlightened constitutional monarchy. However, by 1907, he had become convinced that a republican form of government offered the only hope for Spain. Accordingly, he re-entered the political arena and, although then in his sixties, Galdós took to the hustings with the vigor of a young man and repeatedly gained re-election. As successful as he was at the polls, his bitter denunciations of clericalism and the monarchy as the greatest evils of his day, made him an embattled figure in his later years. The use of his literary works for political purposes (such as the staging of Casandra in 1910) was certainly a factor in his being denied the Nobel Prize in 1912 and led the opposition to denounce him as "the instigator of a revolution of atheists and freethinkers against God, Church, and Fatherland."

It is, therefore, understandable that after his death, official Spain did not encourage publication of Galdós' socially-oriented novels and plays; nor did it view kindly the use of these works in the classroom or as a subject for scholarly investigation. Galdós' death, of course, caused a spontaneous outpouring of newspaper articles throughout
Spain from friend and foe alike. ${ }^{9}$ In addition a few individuals were inspired to write books as a tribute to Galdós: Rafael de Mesa, Don Benito Pérez Galdós. Su familia, sus mocedades, su senectud (Madrid, 1920); Antonio Alarcón Capilla, Galdós y su obra (Madrid, 1922); and Guillermo Dendariena, Galdós. Su genio, su espiritualidad, su grandeza (Madrid, 1922). However after this initial flurry of interest, Spanish intellectuals became, for the most part, relatively silent on the subject of Galdós, and the main focus of enthusiasm for Don Benito and his writings passed from Spain to other countries-to France and England briefly, but principally to the United States where it has remained strong and has, in fact, increased steadily. ${ }^{10}$

In tribute to Galdós, more than 1,000 persons gathered for a velada at Columbia University on April 13, 1920, and heard a eulogy by Professor Hayward Keniston entitled "Galdós, Interpreter of Life." The same year, Hispania began reflecting the interests of galdosistas by publishing this speech, as well as Aurelio Espinosa's laudatory article, "Benito Pérez Galdós" (3, 20306 and 111-12). Later in the 1920's, Professors Arthur Owen (University of Kansas), S. Griswold Morley (California, at Berkeley), and Jacob Warshaw (Missouri) initiated more serious studies concerning Galdós. ${ }^{11}$ However, it was really Professor H. Chonon Berkowitz (Wisconsin) who set the tone for careful and sustained scholarship with a series of important articles in the $1930{ }^{\prime} \mathrm{s}^{12}$ In the era of Roosevelt's New Deal philosophy and programs, liberal idealists discovered a kindred soul in Galdós. ${ }^{13}$ It is not surprising that such a militant thesis novel as Doña Perfecta became a perennial favorite among American college students, and even in some U.S. secondary schools. ${ }^{14}$

The terrible Civil War in Spain finally ended, but proved to be only a prelude to World War II, which disrupted scholarly interests in major universities, not only in Europe but in the United States as well. 
Even the centenary of Galdós' birth in 1943 inspired only one special number among scholarly journals in the United States: Revista hispánica moderna published four articles in his honor. ${ }^{15}$ However, the postwar resurgence of interest in Galdós in this country has continued without interruption for the last twenty-five years. The second half of the 1940's, with its prevailing mood of euphoria and international-mindedness after the successful crusade in Europe, was an exciting era for American colleges and universities. There were highly motivated students in numbers previously undreamed of, and, with great quantities of research going forward in all fields, Spanish studies and scholarly enthusiasm for Galdós flourished.

At this juncture, Galdosian studies benefited greatly from the presence in this country of such distinguished Spanish nationals as Ángel Del Río (Columbia University) and Joaquín Casalduero (Smith College and subsequently New York University), the latter scholar being the author of Vida y obra de Galdós (Buenos Aires, 1943). In addition, William H. Shoemaker (then at Kansas) became a dedicated galdosista and published Galdós' Crónica de la quincena (with critical introduction) in 1948, the same year which saw the posthumous publication of Berkowitz' monumental biography, Pérez Galdós: Spanish Liberal Crusader. ${ }^{16}$

This momentum of interest continued, and the 1950's opened with the publication of a series of major works: Berkowitz' La biblioteca de Benito Pérez Galdós (Las Palmas, 1951), Ángel Del Río's collection of previous articles now entitled Estudios galdosianos (Zaragoza, 1953), Walter T. Pattison's perceptive study concerning the origins of Gloria and Marianela in Pérez Galdos and the Creative Process (Minneapolis, 1954), and Sherman Eoff's penetrating observations on Galdós as a social psychologist in The Novels of Pérez Galdós. The Concept of Life as Dynamic Process (St. Louis, 1954). These scholars and others not only contributed many erudite articles to the corpus of Galdosian studies during the 1950 's, but also trained a whole new generation of students, many of whom have become teachers of graduate seminars and active researchers in the field.

The PMLA annual bibliography bears witness to the fact that the $1960^{\circ}$ s were characterized by an outpouring of learned articles, books, and doctoral dissertations concerning Galdós. Because this last decade of Galdosian studies is so close to us in time, ${ }^{17}$ and the number of works so numerous, we must forego any attempt to list them. Rather, we shall limit ourselves to noting a few occurrences of general interest which will serve to indicate the maturation of the field of Galdosian studies.

The Casa-Museo de Pérez Galdós in Las Palmas, Canary Islands, was inaugurated in 1963, and a number of valuable documents became available to those who wished to study them. ${ }^{18}$ The Casa-Museo, Doña María Galdós de Verde (the author's daughter), and others have placed original manuscripts at the disposal of scholars. As a result, Robert J. Weber has published The Miau Manuscript of Pérez Galdós (Berkeley-Los Angeles, 1964); Anthony García has written a dissertation entitled, "A Critical Study of the Manuscript of Lo prohibido"; 19 Walter T. Pattison is currently studying the manuscript of Gloria; ${ }^{20}$ and Stephen Gilman reports that the Houghton Library of Harvard University has acquired the manuscript of Fortunata y Jacinta. ${ }^{21}$

More and more of Galdós' correspondence is being published, thanks to the efforts of Alfonso Armas, Rodolfo Cardona, Sebastián de la Nuez, Soledad Ortega, Robert Ricard, José Schraibman, William H. Shøemaker, and others. ${ }^{22}$ "Lost" writings by Galdós continue to be found, and specialized bibliographies are becoming available: Theodore A. Sackett has published Pérez Galdós: An Annotated Bibliography (Albuquerque, 1968); another has been an- 
nounced in Spain for this year (compiled by Manuel Hernández Suárez); ${ }^{23}$ and, thanks to Hensley Woodbridge, this issue of Hispania also presents a valuable annotated bibliography.

Galdosian scholars now have access to substantial quantities of the basic materials (biography, bibliographies, complete works, original manuscripts, correspondence, etc.) indispensable for the study of a truly great author. Moreover, during the 1960's galdosistas evolved more and better ways of communicating with each other. Rodolfo Cardona and others founded the Anales galdosianos in 1966, thus giving Galdosian scholars a high-quality, specialized journal comparable to those devoted to such authors as Balzac, Dickens, Shakespeare, and Milton. In 1967, at the Mary Washington College of the University of Virginia (Fredricksburg), Carmen Rivera organized and very graciously presided over the first symposium ever (to our knowledge) devoted entirely to Galdós;, ${ }^{24}$ and on April 15, of this year, the University of Illinois honored Professor William H. Shoemaker, on the occasion of his retirement, with a symposium on Galdós. ${ }^{25}$ However, the most valuable facility for oral communication among galdosistas is, undoubtedly, the yearly conference at the Modern Language Association meeting. Galdosistas obtained permission to hold their first conference in 1966 and have since discussed the following topics: "Galdós and Realism" (1966), "Galdós and Religion" (1967), "Perspectives of Love" (1968), and "La lengua de Galdós" (1969).

Classroom editions of Galdós' novels now include El amigo Manso, Doña Perfecta, La de Bringas, La sombra, Marianela, Miau, and Misericordia. Translations into English also continue at a rapid rate; and although Galdós' greatest novel, Fortunata $y$ Jacinta, has not yet appeared among them, its universal appeal is confirmed by a recent German-language translation and a version this year in French. ${ }^{26}$ That Galdós' novels can and do transcend politi- cal considerations may be seen in the fact that in Spain José María Ribas Bonet's dissertation, "Estudio estilístico de la novela Fortunata y Jacinta de don Benito Pérez Galdós," has won the Menéndez Pidal Prize, ${ }^{27}$ and that scholars in Romania and the Soviet Union are actively publishing the results of their scholarly investigations concerning Galdós. ${ }^{28}$

Because the audience of Hispania is so wide and because our readers possess varying degrees of familiarity with Galdosian studies and with the scholars currently working in the field, we take the liberty of identifying briefly, in alphabetical order, each of the contributors to this issue. In addition, we will also attempt to indicate how each scholar's current research ties in with his previous interests and those of others working in the field, and why or how the present article is of significance. Naturally, within the space allowed, we cannot do justice to even one contributor and his article, not to mention all ten, each of whom has responded with such genuine enthusiasm. If we have misinterpreted anyone's research, we beg his indulgence, for our sole motivation in commenting on each study is the desire to be of service to those readers who may wish orientation to enjoy more fully this special issue.

Professor Joaquín Casalduero was one of the first to comprehend and interpret the entire trajectory of Galdós' writings. His indispensable Vida y obra de Galdós is now in its third (and expanded) edition; ${ }^{29}$ and although Professor Casalduero has written with distinction on many facets of Spanish literature, he has also continued to maintain a lively interest in Galdós throughout his long career (Smith College, New York University, the University of California at San Diego, and the City University of New York). ${ }^{30}$ In his present study, "Conjunción y divergencia de vida $y$ arte en Galdós," Professor Casalduero once again, as in his Vida y obra de Galdós, gives us a panoramic view of Galdós' works and demonstrates now the relationship be- 
tween the character-forming events in the author's own life and the personalities he created for many of his personajes. Specifcally, Professor Casalduero examines the influence of Galdós' mother on the author's life, the reasons he chose not to marry, and the fictional reflection of these factors in the variety of ways his characters react to the mother and/or mother-wife figure throughout the more important novels.

Our collaborator from Britain for this issue, Mrs. Vera Colin, wrote her M.A. thesis on "The Influence of Tolstoy on Galdós" (University of London, 1962) and has since continued her investigations along this same line of inquiry. In "A Note on Tolstoy and Galdós" (Anales galdosianos, 2 [1967], 155-68), she demonstrated the influence of the Russian author on the later novelas contemporáneas: Nazarín (1895), Halma (1895), and El abuelo (1897). Now in 'Tolstoy and Galdós' Santiuste: Their Ideology on War and Their Spiritual Conversion," she shows that this influence also continued into the third series of Episodios Nacionales and that in Aita Tettauen (1905) Galdós still very strongly espoused and reflected the idealism of Tolstoy, especially as found in the Russian writer's Ma Religion (Galdós owned a copy in French translation and obviously used it).

Professor Gustavo Correa (Yale University) is the author of two important books concerning Galdós. In the first, El simbolismo religioso en las novelas de Pérez Galdós (Madrid, 1962), he pointed the way to deeper insights and a fuller appreciation of the religious aspect of Galdós' novels. In the second, Realidad, ficción $y$ simbolo en las novelas de Pérez Galdós. Ensayo de estética realista (Bogotá, 1967), Professor Correa traced the entire chronological evolution of the concept of reality throughout Galdós' social novels (from 1870 to 1915). Now in "Tradición mística y cervantina en las novelas de Galdós, 1890-1897," he continues the interests expressed in his first book and demonstrates that we should take Galdós at his word (expressed in the novel Halma) when he states that the mysticism of his characters is primarily Spanish rather than Russian in origin. In addition, Professor Correa also shows which of the sixteenth-century Spanish mystics, and which of their writings, are reflected in Galdós' novels.

Gerald Gillespie is unique among our collaborators in that his primary training is in Germanic belles-lettres and he holds the title of Professor of Germanic Language and Literature (New York State University at Binghamton). Consequently his discovery of "our" Don Benito and his willingness to devote a part of his research time to Galdós has been an inspiring stimulus to many a galdosista. Professor Gillespie has published in Anales galdosianos and participated in our meetings, including the Galdós Symposium at the Mary Washington College of the University of Virginia in $1967 .{ }^{31}$ His present contribution "Galdós and the Unlocking of the Psyche" is a continuation of his interest on the subject concerning which he read a paper at the annual meeting of the Modern Language Association in 1966.

Walter T. Pattison (Minnesota) is wellknown among readers of Hispania for his very popular two-volume anthology of Spanish literature, Representative Spanish Authors. His very fine and much deserved reputation as a Galdosian scholar derives primarily from his book, Pérez Galdós and the Creative Process, and from a series of scholarly articles on various aspects of Galdós and his works. ${ }^{32}$ Professor Pattison's contribution to this special issue of Hispania, "The Prehistory of the Episodios Nacionales," is a continuation of his longstanding interest in Galdós' creative process; it is another sensitive and convincing demonstration of what probably took place in the author's mind-in this instance, as he evolved a definite over-all plan for writing the first series of his Episodios Nacionales.

Douglass Rogers earned his Ph.D. at 
Wisconsin, in 1964, with a dissertation on contemporary Spanish poetry and now teaches at the University of Texas. Having first demonstrated his interest in Galdós with the sensitive study, "Lenguaje y personaje en Galdós (un estudio de Torquemada)" (Cuadernos hispanoamericanos, 206 [1967], 243-73), he now presents for our readers "The Descriptive Simile in Galdós and Blasco Ibáñez: A Study in Contrasts." In this article Professor Rogers pursues further his interest in Galdós' use of language and initiates an entirely new and (to the best of our knowledge) completely unexplored field of inquiry-a comparison of the imagery in Galdós and Blasco's well-known works: Fortunata $y$ Jacinta and La barraca.

Professor Mario Ruiz (University of Cincinnati) completed his training for the $\mathrm{Ph} . \mathrm{D}$. at Stanford in 1967 with a dissertation on Unamuno. His present study, "El idealismo platónico en Marianela de Galdós," initiates an entirely new field of investigation: the influence of Plato in the novels of Galdós. Beginning now with a single novel (but promising to investigate others in the future), Professor Ruiz shows that Galdós was well acquainted with several of the Greek philosopher's works and indeed drew upon them in the creation of Marianela. Most importantly, Professor Ruiz, although recognizing the valuable contributions of Professors Casalduero and Pattison regarding Comptian philosophy in this novel, suggests Platonism as a corrective as well as an addition to certain aspects of these earlier interpretations.

Professor José Schraibman wrote his doctoral dissertation under the direction of Professor William $\mathrm{H}$. Shoemaker on the subject of "Dreams in the Novels of Galdós" (Illinois, 1959). Subsequently he published it (with the same title, New York, 1960) and has since written numerous articles and collected much of Galdós' personal correspondence. ${ }^{33}$ Now in "El ecumenismo de Galdós," Professor Schraibman focuses primarily upon the novel Miser- cordia and its protagonist Benina-who is very important not only for an understanding of this particular novel but also for comprehending the essence of Galdós' own personal concept of religion. After a review of the preceding novels, Professor Schraibman shows Benina to be the ecumenical culmination of the religious figure in the later novelas contemporáneas, giving us also more light and new angles for a fuller understanding of this character and consequently a deeper appreciation of Galdós' didactic message in Misericordia.

After distinguishing himself in the field of sixteenth-century (pre-Lope) Spanish drama, Professor William H. Shoemaker became a devoted galdosista during the 1940's and has published steadily concerning Don Benito since that time. His interests regarding Galdós are very broad and include, among many other topics, Galdós' "lost" works, his prologues, reappearing characters, and writings expressing literary criticism, the latter to appear soon as $L a$ crítica literaria de Galdós (Madrid, Revista de Occidente). ${ }^{34}$ The major studies of Professor Shoemaker have recently been collected and republished by his colleagues at the University of Illinois in a handsome homenaje volume entitled Estudios sobre Galdós (Valencia: Editorial Castalia, 1970). Professor Shoemaker's present contribution, "'Los Pepes' of Galdós in 1868 and 1887: Two Stages of His Style," is a continuation of his interest in Galdós' "lost" works, and compares two versions of an article, separated by nineteen years. Professor Shoemaker's study is one of the very few to deal with the evolution of Galdós' literary style. He shows that Don Benito not only rewrote the entire article with a conscientious desire to make it more understandable and interesting for South American readers, but also made significant stylistic changes which reflect a more mature and polished manner of writing.

Teachers, students, and researchers will all be grateful to Hensley C. Woodbridge (Southern Illinois University) for his 
very helpful "Benito Pérez Galdós: A Selected Annotated Bibliography," painstakingly prepared especially for this issue of Hispania. Professor Woodbridge deserves our special commendation and gratitude for his patience and adaptability in view of the fact that after he was well along in his project two additional and competing works became available: Theodore A. Sackett's Pérez Galdós: An Annotated Bibliography (Albuquerque, 1968) and Leo J. Hoar's doctoral dissertation, "Pérez Galdós and His Critics" (Harvard, 1965). Accordingly Professor Woodbridge adjusted his own organizational format so that his bibliography may be used in conjunction with these other two works. Specifically, Woodbridge omits criticism contemporary with the appearance of Galdós' social novels and he also uses a different method of annotation-whenever possible letting the individual critic or scholar speak for himself, usually in quotes from his own preface, introduction, and/or conclusion. In addition, and most importantly, Woodbridge supplements the Sackett bibliography by including entries concerning Galdós' Episodios Nacionales, his theater, journalistic writings, prologues, and other short pieces (including cuentos and costumbrista sketches).

Hispania's tribute to Benito Pérez Galdós is a satisfying showcase of Galdosian scholarship in our time: the range of age, experience, and special interests among the contributors attests to the master's vitality as an artist and as a human being. We honor him as Hispanists, but even more importantly, we honor him as humanists.

\section{FOOTNOTES}

${ }^{1}$ See Hensley C. Woodbridge, "Benito Pérez Galdós: A Selected Annotated Bibliography," in this issue of Hispania, pp. 899-971, and Vito Mossa, "Monumento a Galdós," Hispania, 53 (1970), 320.

${ }^{2}$ Symposium, 24 (No. 2, Summer 1970) contains the following articles: Kay Engler, "Notes on the Narrative Structure of Fortunata $y$ Jacinta"; Leo J. Hoar, Jr., " 'Mi Calle' Another 'Lost' Article by Galdós, and a Further Note on his Indebtedness to Mesonero Romanos"; Walter T. Pattison, "How well did Galdós know English?"; B. J. Zeidner Bäuml, "The Mundane Demon: The Bourgeois Grotesque in Galdós' Torquemada en la hoguera"; and Vernon A. Chamberlin, "A Galdosian Statement in 1899 Concerning Dramatic Theory."

3I am indebted to Juan Antonio Maravall, the editor of Cuadernos hispanoamericanos, for the preliminary list of contributors to his special triple issue, Nos. 238-240 (Oct.-Dec.): Juan Bautista Avallae-Arce: "Zumalacárregui"; Francisco Ayala: "Los narradores en las novelas de Torquemada"; Mariano Baquero Goyanes: "Perspectivismo irónico en Galdós"; Donald W. Bleznick' and Mario E. Ruiz: "La Benina Misericordiosa: Conciliación entre la filosofía y la fé"; Carmen Bravo Villasante: " 28 cartas de Galdós a Pereda" and "Polémica en torno a Galdós en la prensa de Santander"; . Rodolfo Cardona: "Nuevos enfoques críticos con referencia a la obra de Galdós"; Joaquín Casalduero: "Historia y novela. Trayectoria de un conflicto"; Alberto Derozier: "El 'pueblo' de Pérez Galdós en La Fontana de Oro"; Willa H. Elton: "Sobre el género de La loca de la casa de Galdós"; Luciano García-Lorenzo: "Bibliografía galdosiana"; Gerald Gillespie: "Miau: Hacia una definición de la sensibilidad de Galdós"; Luis S. Granjel: "Personajes médicos en Galdós"; Jacinto Luis Guereña: "Galdós en notas concéntricas"; Germán Gullón: "Unidad de El Doctor Centeno"; Ricardo Gullón: "Doña Perfecta, invención y mito"; L. J. Hoar, Jr.: "Dos de Mayo de 1.808, dos de septiembre de 1.870, por Benito Pérez Galdós, un cuento extraviado y el posible prototipo de sus Episodios Nacionales"; Vicente Llorens: "Historia y novela en Galdós"; José María López Piñero: "La Medicina y la enfermedad en la España de Galdós"; Andre Nougué: "Antón Caballero, de Benito Pérez Galdós"; Walter T. Pattison: "Verdaguer y Nazarín"; Fernando Quiñones: "Galdós con perro"; Robert Ricard: "Mito, sueño, historia y realidad en Prim"; Eamonn Rodgers: "Realismo y mito en El amigo Manso"; Jorge Rodríguez Padrón: "Galdós, el teatro y la sociedad de su época"; Enrique Ruiz-Fornells: "Benito Pérez Galdós y la crítica norteamericana"; Pierre E. Sallenave: "Notas sobre una lectura política de Galdós"; José Schraibman: "Las citas bíblicas en Misericơrdia de Galdós."

${ }^{4}$ See Woodbridge, as well as España hoy, 1 no. 2, (abril, 1970), 62.

${ }^{5}$ See Woodbridge. I am indebted to Patricia Suzanne Parrent (a Spanish major at the University of Kansas) for sending me a printed program of the stage version of Fortunata y Jacinta from the Teatro Lara, showing the following actors and their roles: Nati Mistral, Fortunata; Lola Herrera, Jacinta; Manuel Tejada, Juanito; and Francisco Merino, Maximiliano.

6James R. Chatham and Enrique Ruiz-Fornells in Dissertations in Hispanic Languages and Literatures: An Index of Dissertations Completed in the United States and Canada, 1876-1966 
(Lexington: Kentucky, 1970) lists fifty-four entries for Galdós, and forty-two for Cervantes.

'Galdós', objectivity and liberalism were, of course, reinforced by his travels abroad, especially to France and England.

${ }^{8} \mathrm{H}$. Chonon Berkowitz, Pérez Galdós: Spanish Liberal Crusader (Madison: Wisconsin, 1948), pp. 398-99.

9See Berkowitz, pp. 455 and 482 as well as Sackett, passim.

${ }^{10}$ In France, S. Scatori published La idea religiosa en la obra de Galdós (Toulouse-Paris, 1927) and in England, Leslie B. Walton contributed Pérez Galdós and the Spanish Novel of the Nineteenth Century (London-Toronto, 1927). Interest in both these nations subsequently revived and presently Prof. Robert Ricard (Sorbonne) is especially active, with many valuable Galdosian studies to his credit.

In Spain, official hostility and lack of scholarly interest were also reinforced by the fact that a new literary movement (which produced the greatest flowering of creative literature since the Golden Age) was in vogue. Although Galdós fared better at the hands of the Generation of '98 than did most of his contemporaries (see Berkowitz, "Galdós and the Generation of 1898," Philological Quarterly, 21 [1942], 107-20), the movement in general rejected Don Benito and his contemporaries. Interest in Galdós, however, revived with the advent of the Second Republic (see Sackett, passim); and when the Civil War erupted, Don Benito became a definite consolation to embattled Loyalists (see, for example, Rosa Chacel's "Un hombre al frente: Galdós," Hora de España, 2 [February, 1937], 47-50). But Galdós' much longed-for Republic fell and consequently, the centenary of his birth (1943) passed almost unnoticed in Spain.

After World War II interest in Galdós was reawakened in Spain. Domingo Pérez Minik explains: "A él se volvía en busca de paz y de conocimiento reparador. . . . Se le volvió a leer como si tratase de un novelista contemporáneo. En realidad, él se nos apareció sobre un plano capaz de aglutinar una nación muy dolorida" (Novelistas españoles de los siglos XIX y XX [Madrid, 1957], pp. 102-03). In 1952 Insula dedicated an entire issue (Año 7, No. 82) to Galdós and in the section "Revisión de Galdós" spoke of a "vuelta a Galdós, de una revisión radical de la obra galdosiana, quizá iniciada desde América, donde su vida y su obra han sido objeto, en estos quince últimos años, de mayor atención" (p. 3). Since that time, interest has increased steadily-both in mainland Spain and the Canary Islands-and has reached the point where younger Spaniards no longer esteem Galdós exclusively for his Episodios $\mathrm{Na}$ cionales, but also for his socially oriented novels and plays. Moreover, the latter are now considered worthy and vital subjects for doctoral dissertations (see note 27); and, in many ways, during this anniversary year Spaniards are also joining with us in paying tribute to their great author.
${ }^{11}$ Arthur L. Owen, "The Torquemada of Galdos," Hispania, 7 (1924), 165-70; S. Griswold Morley, "Introduction" [to the play] Mariucha (Boston: D. C. Heath, 1921); and Jacob Warshaw, "The Casa-Museo de GaldósFor Sale?," Hispania, 10 (1927), 225-36; "Errors in Biographies of Galdós," Hispania, 11 (1928), 485-99; and "Galdós' Indebtedness to Cervantes," Hispania, 16 (1933), 127-42.

12Among others, "Galdós and Mesonero Romanos," Romanic Review, 23 (1932), 201-05; "The Youthful Writings of Pérez Galdós," Hispanic Review, 1 (1933), 91-121; and 'Galdós' Literary Apprenticeship," Hispanic Review, 3 (1935), 1-22.

13This spiritual and emotional identification intensified with the outbreak of Spain's Civil War. Some American college students went off to fight with the Abraham Lincoln Brigade. Donald E. Henry, to cite but one example, was an idealistically motivated student at the University of Kansas who volunteered for service in Spain and died there in 1937. Subsequently, the University named a co-operative dormitory in his honor; but when the Abraham Lincoln Brigade was later declared a subversive, Communistfront organization, Mr. Henry's advisor in the Spanish department was forced to submit to a federal inquiry.

14The Library of Congress Author Catalog (Ann Arbor: Michigan, 1953, xvi, 262-63) lists more classroom editions and English-language translations of Doña Perfecta than any other Galdosian novel. For the continued interest in, as well as new ideas concerning, Doña Perfecta for high school teaching, see David J. Curland, "Galdós and the Advanced Spanish Class in High School," Hispania, 52 (1969), 873-76.

${ }_{15}$ Revista hispánica moderna, 9 (1943), published the following short articles: Francisco García Lorca, "El realismo de Galdós," 289-90; Angel del Río, "Los ideales de Galdós," 290-92; Tomás Navarro, "La lengua de Galdós," 292-93; and Federico de Onís, "El humorismo de Galdós," 293-94. For those published in other coun. tries, see Woodbridge, p. 902.

16Shoemaker's edition of Galdós' Crónica was published by Princeton University, and the Berkowitz biography by the University of Wis. consin.

${ }^{17}$ One recalls Galdós' statement in 1879 , say. ing he planned to write no further Episodios Nacionales; because "los años que siguen ... están demasiado cerca, nos tocan, nos codean, se familiarizan con nosotros. . . . Son años a quienes no se puede disecar, porque algo vive en ellos que duele, y salta al ser tocado con escalpelo." In "Un faccioso más y algunos frailes menos," Obras completas, 4a ed. (Madrid, 1958), in, 317.

"For photographs of the museum, see Alfonso Armas, "La Casa-Museo de Pérez Galdós," Mundo hispánico, No. 196 (julio 1964), 49-51.

19Pittsburg, 1969. (See Claude L. Hulet, "Dissertations in Hispanic Languages and Litera. ture-1969," Hispania, 53 [1970], 231.) 
20See Pattison, "The 'Prehistory' of the Episodios Nacionales," this issue of Hispania, p. 000 .

21"Narrative presentation in Fortunata $y$ Jacinta," Revista hispánica moderna, 34 (1968), 293.

22Alfonso Armas, "Galdós y sus cartas," Papeles de Son Armadans, 40 (1966), 9-36; Rodolfo Cardona, "Un olvidado texto de Galdós," Anales galdosianos, 3 (1968), 151-54; Sebastián de la Nuez, "Cartas de Miguel de Unamuno a Galdós," Papeles de Son Armadans, 37 (1965), 145-78, and "Unamuno y Galdós en sus cartas," Insula, 19, nos. 216-17 [sic] (1964), 29; Sebastián de la Nuez and José Schraibman, Cartas del archivo de Pérez Galdós (Madrid, 1967); Soledad Ortega, Cartas a Galdós (Madrid, 1964); Robert Ricard, "Cartas de Ricardo Ruiz Orsatti a Galdós acerca de Marruecos (1901-1910)," Anales galdosianos, 3 (1968), 99-117; José Schraibman: "Cartas de Manuel Tolosa Latour a Galdós," El museo canario, $77-84$ (1961-62), 171-86; "Cartas de 'Tolosa Latour a Galdós," Insula, 6 (No. 179, October 1961), 3; "Cartas inéditas de Galdós," Symposium, 16 (1962), 115-21; "Cartas inéditas de Pérez de Ayala a Galdós," Hispanófila, 6, (No. 16, enero 1963), 83-103; and "An unpublished Letter from Galdós to Ricardo Palma," Hispanic Review, 32 (1964), 65-68; and William $H$. Shoemaker, "Una amistad literaria: La correspondencia epistolar entre Galdós y Narciso Oller," Boletín de la Real Academia de Buenas Letras (Barcelona), 30 (1963-64), 247-306; and "Cartas de Pereda a Galdós y ocho borradores," Boletín de la Biblioteca de Menéndez Pelayo, 42 (1966), 131-72.

${ }^{23}$ Anales galdosianos, 3 (1968), 191.

${ }^{24}$ The program was as follows: Session I, Galdós and the 'Twentieth Century: Sherman Eoff, "Motives and Values in Galdós, with Attention to the Twentieth Century"; Joaquín Casalduero, "Galdós está vivo"; and José Angeles, "Galdós y la actualidad." Session II, Galdós and Spain: José Schraibman, "Galdós, Spanish Visionary"; and Vernon A. Chamberlin, "Doña Perfecta: Light and Darkness, Good and Evil." Session III, Galdós and the Nineteenth Century: Rodolfo Cardona, "Galdós and Realism"; Walter T. Pattison, "Galdós and Naturalism"; and Gerald Gillespie, "Galdós and Positivism."
These papers were subsequently xeroxed, bound, and distributed by Carmen Rivera and entitled Galdos: Papers Read at the Modern Foreign Language Symposium . . . Fredricksburg, Va., April 21-22, 1967.

25Joaquín Casalduero presented the principal paper, "Novela e historia en Galdós"; José Schraibman read "El ecumenismo de Galdós"; and Vernon A. Chamberlin contributed "The Significance and Artistry of the Sound Effects in Galdós' Doña Perfecta."

${ }^{26}$ The German-language translation is Fortunata und Jacinta: Zwei Geschichten von Ehefrauen (Zurich, Switzerland, Manesse Verlag, 1961); and the French, Fortunata et Jacinta. Histoire de deux femmes mariées (Lausanne: Editions Recontre, 1970).

${ }^{27}$ Announced in PMLA, 85 (1970), 130. I am indebted to Professor Ribas Bonet for providing me with a copy of his dissertation.

28Romania: Andrei Ionescu, "Napoleón Bonaparte visto por Benito Pérez Galdós en la primera serie de los Episodios Nacionales," Analele Universitatii Bucaresti, 15 (1966), 127-33 (according to José Simón Díaz, in "Información bibliográfica," Revista de literatura, 33 (1968), 227.

Soviet Union: Chistiakova, V. V., "Antiklerikal'nye dramy Gal'dosa [Galdós' Änti-clerical Dramas],"Uchenye zapiski gos. mauchno-issled. in-ta teatra i musyki, 1 (1958), 429-68; and Chernushenko, E. M., "Osobennosti portretnoi i rechevoi kharacteristiki $v$ rannen tvorchestve Gal'dosa. Pervaia seriia 'Natsional' nykh epizodov'" [The Special Techniques of Portraiture and Speech Characterization in Galdós' First Series of Episodios Nacionales]," Uchenye zapiski Leningradskoyo pedagogicheskago in-ta im. A. I. Gerstsena, 211 (1959), 169-85.

${ }^{29}$ The first edition was published by Losada, Buenos Aires, 1943, and the second and third by Gredos, Madrid, 1961 and 1970.

${ }^{30}$ See Sackett, pp. 31-34; also notes 3, 24, and 25.

31 See note 24 , also note 3 .

${ }^{32}$ See Sackett, pp. 88-89; also notes 2, 3, and 24.

33See Sackett, pp. 109-11; also notes 3, 24, and 25.

${ }^{34}$ See Sackett, pp. 111-12. 